DOI

\title{
РОЗВИТОК ДІТЕЙ, НАРОДЖЕНИХ ІЗ ЗАСТОСУВАННЯМ ДОПОМІЖНИХ РЕПРОДУКТИВНИХ ТЕХНОЛОГІЙ: ПСИХОСОЦІАЛЬНІ АСПЕКТИ У ПЕРІОДІ ВАГІТНОСТІ ТА ОСОБЛИВОСТІ СТАНУ ЗДОРОВ'Я НА ПЕРШОМУ РОЦІ ЖИТТЯ
}

\section{Одеський національний медичний університет}

○В. В. Синенко

\begin{abstract}
РЕЗЮМЕ. У роботі проведено аналіз захворюваності, динаміки психофізичного розвитку 28 дітей, народжених із застосуванням ДРТ, на першому році життя. Встановлено, що такі діти мають певні закономірності росту і розвитку, а також широкий спектр діагностованої патології. Паралельно проведено порівняльне обстеження вагітних жінок, які попередньо спостерігалися з приводу безпліддя, задля виявлення особливостей різних сфер життєдіяльності. Отримані дані дозволили зробити висновок щодо необхідності оптимізації спостереження дітей та жінок означених категорій.

КЛЮчОВІ СЛОВА: діти, допоміжні репродуктивні технології, психофізичний стан.
\end{abstract}

Вступ. Актуальність проблеми безпліддя підтверджують дані статистичних досліджень: кожна 5 пара в Україні стикається з цим діагнозом. За визначенням ВОО3, безпліддя (Sterilitas) - це нездатність пари в дітородному віці зачати дитину впродовж 1 року регулярного статевого життя без використання засобів і методів контрацепції $[4,5]$. Слід підкреслити, що безпліддя негативно впливає як на соматичне здоров'я, так і на психоемоційний стан жінки, що потребує поглибленого вивчення [6].

Завдяки сучасним методам репродуктивної медицини проблема безпліддя має реальні перспективи вирішення [1]. Нині в усьому світі зареєстровано понад 1 млн дітей, які народилися внаслідок застосування допоміжних репродуктивних технологій (ДРТ). За даними багатьох вітчизняних та іноземних авторів, діти, які народжені внаслідок застосування ДРТ, мають певні особливості розвитку і стану здоров'я [2]. Сучасні тенденції широкого використання методів репродуктивної медицини обґрунтовують доцільність проведення дослідження стану здоров'я і розвитку дітей, що народжені за допомогою ДРТ [3].

Матеріал і методи дослідження. Проведено клініко-анамнестичне обстеження 46 дітей у віці до 1 року, серед них 21 хлопчик та 25 дівчат. Для виявлення клініко-анамнестичних особливостей у дітей, народжених за допомогою ДРТ, використовували спеціально розроблену картку обстеження, що містила дані відносно варіанту безпліддя, рівня медикаментозного навантаження, наявності персистуючої інфекції, особливостей перебігу вагітності і пологів у матері, а також особливості перинатального періоду, показники фізичного розвитку та захворюваності дитини.

Паралельно в обстеженні взяли участь 50 жінок, які проходили обстеження в клініці Допоміжних репродуктивних технологій, у результаті чого наступила вагітність і народилися діти. Контрольну групу склали 50 жінок, які перебували на обліку в жіночій консультації з приводу фізіологічної вагітності. Всім обстежуваним пропонували заповнити спеціально розроблену анкету-опитувальник. Питання, включені в анкету (загалом 40 позицій), сформували 5 основних модулів: соціальний, психологічний, духовний, медичний і фінансовий.

При проведенні статистичної обробки отриманих даних визначалися основні загальноприйняті характеристики: середня, помилка середнього і стандартне відхилення. Достовірність відмінностей аналізували за допомогою критерію Стьюдента. Зв'язок між показниками оцінювали за допомогою розрахунку відносин шансів (odds ratio, OR) та їх довірчих інтервалів (confidence interval $-\mathrm{Cl}$ ). Перевірку гіпотез про рівність двох середніх виконували з використанням U-тесту Манна-Уїтні.

Результати й обговорення. Аналіз отриманих даних показав, що у дітей, народжених внаслідок застосування ДРТ, обтяжений акушерський анамнез (попередні аборти, викидні, безпліддя) мав місце у 65,2 \% жінок, оперативне розродження було проведене у 50 \% випадків. При дослідженні основних показників фізичного розвитку (довжина і маса тіла, обхват голови і грудної клітки) не встановлено суттєвої різниці з референтними значеннями, втім порівняння динаміки кривої маси тіла та обхвату грудної клітки демонструвало тенденцію до зменшення означених розмірів. Формування моторики показало дещо сповільнений розвиток, а саме більш пізні строки самостійного утримування головки, засвоєння функції сидіння, а також запізнілий час появи першого зуба. У спектрі захворювань найпоширенішою була невропатологія - $(86,95 \pm 4,96) \%$. Аномалії розвитку і ознаки морфофункціональної недозрілості встановлено у $(54,34 \pm 7,34) \%$ обстежених. Дефіцитні стани, як-то анемія, рахіт зустрічалися у $(43,47 \pm 7,3)$ та 
Огляди літератури, оригінальні дослідження, погляд на проблему

$(4,34 \pm 3,0)$ \% дітей відповідно. На першому році життя алергічні прояви (атопічний дерматит) з'явилися у $(13,04 \pm 4,96) \%$ дітей, нефропатію діагностовано у $(10,86 \pm 4,58) \%$, гострі респіраторні захворювання перенесли $(41,30 \pm 7,25) \%$ обстежених.

Проведений аналіз особливостей життєдіяльності проанкетованих жінок продемонстрував, що безпліддя спричинює цілу низку особливостей не лише медичного характеру, зокрема соматичного стану здоров'я.

При обробці отриманих анкет внутрішньогруповий аналіз продемонстрував, що на фоні безпліддя у жінок найнеблагополучнішими сферами $\epsilon$ психосоціальна і медична, тоді як у жінок контрольної групи найпроблемнішими були фінансова і соціальна сфери.

Для виділення найбільш значущих несприятливих факторів проводили детальний аналіз досліджуваних модулів. Насамперед аналізували психологічні та соціальні аспекти обговорюваної проблеми.

У психологічному модулі у жінок основної групи отримані достовірно $(p<0,05)$ нижчі показники при оцінці емоційної сфери. Недолік позитивних емоцій, поганий настрій були відзначені у $(54,0 \pm 7,05) \%$ респондентів. Періодично депресивний стан і тривогу відчували $(20,0 \pm 5,6) \%$ обстежених.

Достеменно низькі показники $(p<0,05)$ також були продемонстровані у відповідях, що стосуються зовнішності. Незадоволеність своєю зовнішністю відзначили $(10,0 \pm 4,24) \%$ жінок основної групи. При цьому у більшості респондентів виявлено достовірно $(p<0,05)$ низький рівень самооцінки. Загальну незадоволеність собою, проблеми самореалізації особистості виявили $(34,0 \pm 6,7) \%$ жінок.

На нестачу спілкування з близькими людьми, що супроводжується переживанням і почуттям самотності, вказали $(22,0 \pm 5,8) \%$. У анамнезі в $(40,0 \pm 6,9) \%$ жінок, які страждають безпліддям, були виявлені тяжкі психологічні потрясіння, тоді як в контрольній групі рівень таких подій був значно нижчим - $(18,0 \pm 5,43) \%, \mathrm{p}<005$.

У ході аналізу стану психологічної сфери було встановлено, що ризик безпліддя збільшують: нестача позитивних емоцій, депресія, тривога, поганий настрій або $=5,5$ (ДІ: 95\%: 2,24; 3,38).

Значимо низькі показники у жінок основноїгрупи були отримані і в сфері соціальних взаємин. Так, незадоволеність взаєминами з рідними виявили $(24,0 \pm 6,1) \%$ жінок основної групи, і тільки $(6,0 \pm 3,4) \%$ опитаних жінок з групи контролю, $p<0,01$.

Дефіцит інформації щодо проблеми безпліддя та шляхів ії вирішення відзначили $(18,0 \pm 5,4) \%$ жінок. Характерно, що більшість респондентів $(80,0 \pm 5,6) \%$ вказували на незадоволеність доступністю і якістю медико-соціальної допомоги.

Водночас слід зазначити, що в духовній сфері у жінок з безпліддям виявлені достовірно вищі показники. Зокрема, поглиблення релігійних поглядів спостерігалося у $(24,0 \pm 6,1) \%$ жінок основної групи і у $(4,0 \pm 2,8) \%$ жінок контрольної групи $(p<0,01)$. Характерно, що більше половини опитаних жінок основної групи вказували на зміцнення сімейних традицій, збільшення часу для здійснення своїх духовних потреб.

Висновки. Особливості психофізичного розвитку, частота та структура захворювань малюків, народжених із застосуванням ДРТ, свідчить про необхідність тривалого і комплексного спостереження за даним контингентом дітей.

Зважаючи на те, що у жінок з порушенням репродуктивного здоров'я спостерігаються певні проблеми не лише з суто медичних аспектів, але й з боку психосоціальної сфери життя, програми предгравідарної підготовки мають бути індивідуалізованими та передбачати проведення психологічної корекції.

Перспективи подальших досліджень. Планується подальше дослідження даної групи дітей у більш зрілому віці, а також розробка не інвазивних методів дослідження.

\section{ЛІТЕРАТУРА}

1. Phenotypic differences in children conceived from fresh and thawed embryos in vitro fertilization compared with naturally conceived children / Green M. P., Mouat F., Miles H. L. [et al.] // Fertil. Steril. - 2013. - № 99. P. 1898-1904.

2. Henningsen Karina Aaris. Study of babies born after IVF shows significant improvements in health over 20 years // Human Reproduction. - 2015. - № 20. - P. 20.

3. Health and disease in children born after assistive reproductive therapies (ART) / Hyrapetian Mariyum, Loucaides Eva M., Sutcliffe Alastair G. // Published Online. 2014. - № 17. - P. 21.
4. Prevalence of deressive and anxiety disorders in an assisted reproductive technique clinic / T. H. Chen, S. P. Cheng, C. F. Tsai, K. D. Juang // Hum Reprod. - 2004. № 19. - P. 2313-2318.

5. The effect of anxiety and depression on the outcome of in-vitro fertilization / J. M. Smeenk, C. M. Verhaak, A. Eugster [et al.] // Hum Reprod. - 2001. - № 16 (7). P. 1420-1423.

6. Boivin J. Emotional distress in infertile women and failure of assisted reproductive technologies: meta-analysis of prospective psychosocial studies / J. Boivin, E. Griffiths, C. A. Nenetis // BMJ. - 2011. - № 342. - P. 223. 


\section{Odesa State Medical University}

SUMMARY. This paper analyzes the morbidity, mental and physical development dynamics of 28 children born using ART in the first year of life. It was established that these children have certain patterns of growth and development, and a wide range of diagnosed pathology. In parallel, a comparative examination of pregnant women who previously experienced infertility, to identify the characteristics of different areas of life. The data led to the conclusion on the need to optimize the observation of children and women the aforementioned categories.

KEY WORDS: children, assisted reproductive technology, psychophysical condition. 